\title{
PENGARUH MODEL PEMBELAJARAN SNOWBALL THROWING TERHADAP KEMAMPUAN MENULIS BERITASISWA MTSN 4 SUKABUMI
}

\author{
Paridudin ${ }^{1}$ Deden Ahmad Supendi ${ }^{2}$ Asep Firdaus ${ }^{3}$ \\ paridudinparid455@gmail.com \\ Universitas Muhammadiyah Sukabumi
}

\begin{abstract}
Abstrak. Tujuan penelitian ini untuk mendeskripsikan metode pembelajarann snowball throwing dalam pembelajaran menulis unsur-unsur berita serta hasil menulis sebelum dan sesudah menggunakan metode snowball throwing. Teknik pengumpulan data dilakukan dengan pretest dan posttest.sampel penelitiannya ialah siswa kelas VIII MTsN 4 Sukabumi . Penelitian ini dilaksanakan dengan menggunakan desain penelitian One Grup pretes-Posttes Design. Berdasarkan hasil analisis tes awal diperoleh nilai tertinggi yaitu 95 nilai terendah 10. Sedangkan pada tes akhir nilai tertinggi 100 dan nilai terendah 40 . Hasil $t_{\text {hitug }}$ yaitu 7,94 da $\mathrm{t}_{\text {tabel }}$ 1,699 maka $\mathrm{H}_{1} \# \mathrm{H}_{0}$ hipotesis tidak sama dengan yang diduga.model pembelajaran snowball throwing mempengaruhi dalam meningkatkan keterampilan menulis unsur-unsur teks berita siswa kelas VIII MTsN 4 Sukabumi.
\end{abstract}

Kata Kunci: menulis unsur berita, snowball throwing.

Abstrac. The purpose of reearh is to describe the methods learning snowball throwing in learning to write elements of the news and proceeds to write before and after using the method of snowball throwing. Mechanical colection of data is done with pretest and posttest .Sample research is student class VIII MTsN 4 Sukabumi . Research is carried out by using the design study One group pretest- posttest design. Based on the results of the analysis of the test beginning of acquired value of the highest ie 95 grades lows 10. While the tests end value of the highest 100 and the value lowest 40 . H acyl t count is 7.94 da t table 1.699 then $\mathrm{H} 1 \mathrm{HH}$ 0 hypothesis is not equal to that allegedly model learning snowball throwing influence in increasing the skills of writing elements of text news studentsclass VIII MTsN 4 Sukabumi

Key words: write elements of news, snowball throwing.

\section{PENDAHULUAN}

Tarigan (2008:3) keterampilan berbahasa adalah sesuatu yang penting bagi setiap orang saling berinteraksi dengan orang lain dengan cara komunikasi. Adapun cakupan keterampilan berbahasa meliputi keterampilan berahasa keterampilan menyimak, berbicara, membaca dan menulis.

Menulis sebagai salah satu aspek dari keterampilan berbahasa merupakan sebuah rangkaian kegiatan seseorang dalam menuangkan penyampaiannya melalui bahasa tulis kepada pembaca.

Tarigan (2008.3), keterampilan menulis adalah salah satu keterampilan berbahasa yang produktif dan ekspresif. Menulis dipergunakan untuk berkomunikasi secara tidak langsung dengan tidak bertatap muka dengan pihak lain. Keterampilan ini menciptakan suasana yang mendorong proses kegiatan belajar mengajaryang tidak monoton atau suasana pembelajaran yang selalu membuat bosan para siswa. Salah satu kegiatan yang menuntut siswa memiliki keterampilan iniadalah pada materi menulis pokok-pokok berita.

Menulis pokok-pokok berita merupakan salah satu materi yang wajib dipelajari oleh siswa di sekolah. Berita sebagai salah satu jenis informasi yang berisi pengetahuan sudah menjadi kebutuhan pokok semua masyarakat. Pun demikianTeks berita jika dilihat dari pola pengembangan teksnya termasuk ke dalam jenis teks eksposisi.

Dikatakan demikian karena jenis informasi yang berguna bagi kehidupan manusia, selain itu, teks eksposisi termasuk ke dalam jenis tulisan yang bertujuan untuk memaparkan, menjelaskan, menyampaikan informasi, mengajarkan, dan menerangkan suatu topik. Ketika kegiatan pembelajaran menulis berita siswa pada pelaksanaannya terkadang kesulitan dalam menuangkan ide serta gagasannya tanpa ada rangsangan kepada siswa atau tidak menggunakan model pembelajaran sehingga keterampilan menulis siswa sangat rendah. Model pembelajaran sangatlah penting untuk merangsang siswa dalam proses 


\section{Paridudin $^{1}$ Deden Ahmad Supendi ${ }^{2}$ Asep Firdaus ${ }^{3}$ \\ PENGARUH MODEL PEMBELAJARAN SNOWBALL THROWING TERHADAP KEMAMPUAN MENULIS BERITASISWA MTSN 4 SUKABUMI}

pembelajaran, untuk lebih memudahkan siswa dalam menuangkan ide atau gagasan sehingga tidak kesulita dalam menuliskan sebuah cerita. Karena rendahnya minat keterampilan menulis, sehingga dibutuhkan model pembelajaran baru. Demikian pula dengan pemberian materi-materi yang lain siswa tidak mengalami perubahan yang signifikan terhadap prilakunya, dalam hal ini dapat dijadikan kajian bagi kita semua terutama bagi penulis, orang tua, pemerintah,masyarakat khususnya yang bertanggungjawab dalam pendidkan baik di sekolah umum maupun khusus demi mencapai tujuan dan cita-cita nasional bangsa Siswa dalam menulis teks berita dituntut untuk lebih bisa berimajinatif dalam menuliskan ceritanya, siswa terkadang mengalami kendala dalam menuangkan ide dan gagasanya tanpa menggunakan rangsangan atau dorongan berupa penggunaan model pembelajaran yang cocok dan tepat terhadap materi yang sesuai kita ajarkan, tanpa penggunaan model pembelajaran yang inovatif, kreatif dan menyenangkan maka hasilnya lebih rendah. Penggunaan model pembelajaran sangatlah penting untuk merangsang semangat dan jiwa kreatif dalam proses pembelajaran, untuk lebih memudahkan siswa dalam menuangkan ide atau gagasan sehingga tidak merasa kesulitan dalam menuliskan sebuah teks berita. Rendahnya kemampuan siswa dalam menuliskan teks beita diakibatkan oleh model pembelajaran yang monoton.

Permasalahan tersebut bisa diatasi dengan terobosan baru yaitu berupa model pembelajaran yang tidak monoton, diharapkan dengan model tersebut keterampilan menulis siswa dapat ditingkatkan kembali. Salah satu model pembelajaran yang mendukung proses keterampilan menulis untuk meningkatkan proses pembelajaran aktif, inovatif dan menyenangkan ialah model snowball throwing.

Model snowball throwing. ini memadukan pendekatan komunikatif, integrative, serta keterampilan proses dalam berbahasa. Kegiatan melempar bola pertanyaan ini akan membuat menjadi dinamis, karena kegiatan siswa tidak hanya berpikir, menulis, bertanya, atau berbicara. Akan tetapi mereka juga melakukan aktivitas fisik yaitu melemparkannya bola kertas pada siswa lain. Dengan demikian, tiap anggota akan mempersiapkan diri karena pada gilirannya mereka harus menjawab pertanyaan dari temannya yang terdapat dalam kertas.

Metode Snowball Throwing pada prosesnya, guru berusaha memberikan kesempatan kepada siswa untuk mengembangkan keterampilan menulis pokok-okok berita atau informasi yang mereka proleh dalam konteks nyata dan situasi yang kompleks. Guru juga memberikan pengalaman kepada siswa melalui pembelajaran terpadu dengan menggunakan proses yang saling berkaitan dalam situasi dan konteks komunikasi alamiah baik sosial, sains hitungan dan lingkungan pergaulan. Dalam pengaturan kelas dibentuk secara konvensional atau berbentuk angka $U$ kemudian masingmasing siswa menjawab pertanyaan dari bola yang diperoleh.

Penelitian model pembelajaran snowball throwing ini sebelumnya sudah dilakukan oleh Septi Eka Sukowati dan Intan Noviana Safitri. Septi Eka Sukowati melakukan penelitiannya dengan judul "Pengaruh Model Snowball Throwing Terhadap Kemampuan Menulis Teks Berita Siswa Kelas VIII SMP Negeri 4 Kota Jambi”, Sedangkan Intan Noviana Safitri,"Pengaruh Penerapan Model Pembelajaran Kooperatif Tipe Snowball Throwing Terhadap Hasil Belajar Siswa Kelas XI IPS I Pada Mata Pelajaran Ekonomi Di SMAS 3 Pasundan Bandung tahun pelajaran 2018/2019.

Dengan menggunakan model

pembelajaran Snowball Throwing proses pembelajaran tidak monoton lagi sehingga akan lebih terarah dalam keterampilan menulis pokok-pokok berita, siswa akan lebih mudah berpikir dan berimajinasi dalamproses menuangkan ide dan gagasan kedalam bentuk tulisan. Sehingga keterampilan menulis dapat ditingkatkan kembali. Oleh sebab itu penulis melakukan penelitian yang berjudul "Pengaruh Model Pembelajaran Snowball Throwing Terhadap Kemampuan Menulis Pokok-Pokok Berita Siswa Kelas VIII MTsN 4 Sukabumi”.

\section{METODE PENELITIAN}

Metode penelitian ini menggunakan metode penelitian kuantitatif. Untuk mengukur kemampuan siswa sebelum dan sesudah diberikan perlakuan dengan model pembelajaran Snowball Throwing. Hal ini dilakukan untuk mengukur adakah perbedaan kemampuan siswa menulis teks berita sebelum dan sesudah diberikan perlakuan model pembelajaran. Selain itu proses tersebut dilihat pula seberapa besar pengaruh model pembelajaran Snowball Throwing terhadap kemampuan menulis unsur-unsur berita Kegiatan penelitian ini dilaksanakan selama satu minggu tepatnya pada bulan Februari 2020, meliputi persiapan dan pelaksanaan.adapun seluruh rangkaian kegiatan penelitian ini bertempat MTsN 4 Sukabumi Jalan Raya Galumpit Rt 020/004 Desa Sukamukti Kecamatan 


\section{Paridudin $^{1}$ Deden Ahmad Supendi ${ }^{2}$ Asep Firdaus ${ }^{3}$ \\ PENGARUH MODEL PEMBELAJARAN SNOWBALL THROWING TERHADAP KEMAMPUAN MENULIS BERITASISWA MTSN 4 SUKABUMI}

Waluran Kabupaten sukabumi. Teknik pengumpulan data yang penulis gunakan dalam penelitian ini penulis memberikan tes dan lembar observasi kisikisi instrument serta lembar observasi guru dan siswa kemudian siswa diberi tugas untuk membuat karangan narasi sesuai dengan unsur yang terkandung dalam karangan eksposisi, dalam tes ini siswa diberikan dua kali pengujian tes. Prates dilakukan sebelum diberikan perlakuan, dan pascates setelah diberikan perlakuan siswa kelas VIII.2 MTsN 4 Sukabumi yang berjumlah 30 siswa tahun pelajaran 2019/2020. Desain penelitian yang digunakan pada penelitian ini yaitu menggunakan desain penelitian One Grup pretes-Posttes Design, pada penelitian ini dilakukan dengan menggunakan satu kelas, tidak menggunakan kelas control sebagai pembanding. Desain ini bisa digambarkan sebagai berikut:

Desain Penelitian

\section{$\mathrm{O}_{1} \times \mathrm{O}_{2}$}

$\mathrm{O}_{1}=$ Nilai Pretest (sebelum diberi perlakuan $\mathrm{X}=$ Treatmen

$\mathrm{O}_{2}=$ Nilai Posttest (setelah diberiperlakuan) (Sugiyono, 2016:111)

Menurut Sujarweni (2014:65) populasi adalah keseluruhan jumlah yang terdiri atas objek atau subjek yang mempunyai karakteristik dan kualitas tertentu yang ditetapkan oleh peneliti untuk diteliti dan kemudian ditarik kesimpulannya. Adapun sumber data yang diambil berdasarkan data di bawah ini, penulis mengambil data dari staf tata usaha MTsN 4 Sukabum Jalan

Raya Galumpit Desa Sukamukti Kecamatan Waluran. Berdasarkan hal tersebut populasi dalam penelitian ini adalah semua peserta didik kelas VIII MTsN 4 Sukabumi dengan jumlah keselurahan 117 Orang terdiri dari 62 laki-laki 55 perempuan.

\section{HASIL DAN PEMBAHASAN \\ 1. Hasil Penelitian}

Penelitian ini bertujuan untuk mengetahui pengaruh model pembelajaran snowball throwing terhadap kemampuan menulis pokok-pokok berita siswa kelas VIII MTsN 4 Sukabumi. Data diperoleh dari nilai pretest yang dijadikan sebagai data awal serta nilai posttest yang dijadikan sebagai data akhir.
Berdasarkan tabel hasil pretest nilai yang terendah adalah 10 dan nilai paling tinggi yang diperoleh oleh siswa yaitu 95 Untuk pada saat pretest yaitu dengan menggunakan rumus sebagai berikut mengetahui nilai yang diperoleh oleh siswa Berdasarkan tabel uji perbedaan pretest dan posttest,maka dapat disimpulkan bahwa hasil yang didapat ialah hasil $t_{\text {hitung }}$ 7,94 dan pada saat pretest. Berdasarkan perhitungan uji-t signifikan hasil yang diperoleh bahwa tesawal (pretest) dan tes akhir (posttest) signifikan. Hal ini terbukti setelah dilakukan uji-t signifikan pretest dan posttest dapat dilihat dari hasil

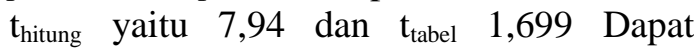
disimpulkan bahwa dalam penelitian menganalisis unsur teks berita dengan menggunakan model pembelajaran snowball throwing sangat berpengaruh karena thitung $>t$ tabel.

Hipotesis yang digunakan oleh peneliti yaitu menggunakan uji-t $c$ signifikan. Hal ini disebabkan karena uji-t pretest dan posttest meningkat atau mengalami perubahan menjadi lebih baik dan lebih besar $\mathrm{t}_{\text {-hitung }}$ dibanding dengan $\mathrm{t}$ tabel. Maka dapat diambil kesimpulan uji pretest dan postes mengalami peningkatan yang signifikan. Begitu juga dengan jumlah yang lebih kecil dari t-tabel maka dapat diartikan kemampuan siswa meningkat.

\section{SIMPULAN}

Berdasarkan penelitian yang dilakukan oleh peneliti di MTs Negeri 4 Sukabumi jikadihubungkan dengan rumusan masalah maka dapat disimpulkan bahwa: pertama kemampuan menganalisis unsurunsur teksberita sebelum menggunakan model pembelajaran snowball throwing maka hasil nilainya masih jauh dari maksimum dengan nilai awal pretest yaitu mendapatkan nilai terendah 10 sedangkan nilai tertingginyayaitu 90 yang berarti siswa belum mampu memahami pembelajaran tentang materi menganalisis unsur-unsur teks berita dengan baik. Pada pelaksanaan pretest beberapasiswa tampak mengalami kesulitan dalam menganalisis unsur-unsur teks berita serta dedikasi semangat serta kreativitas dalam pelaksanaan pembelajarannya masih kurang. Kedua, kemampuan menganalisis unsur- unsur teks berita setelah menggunakanmodel

Pemebelajran snowball throwing mengalami perubahan, hal ini dapat dilihat dari nilai hasil posttest dengan niali terendah yaitu 40 dan nilai tertinggi yaitu 100 itu artinya siswa sudah cukup mampu memahami materi pembelajaran menganalis unsur-unsur teks berita, perubahan tersebut dapat didukung oleh data hasil observasi 


\section{Paridudin $^{1}$ Deden Ahmad Supendi ${ }^{2}$ Asep Firdaus ${ }^{3}$ \\ PENGARUH MODEL PEMBELAJARAN SNOWBALL THROWING TERHADAP KEMAMPUAN MENULIS BERITASISWA MTSN 4 SUKABUMI}

yang telah dilaksanakan oleh peneliti. Mengalami perubahan aktivitas siswa yang dimulai dari kesiapan, pemahaman, dan tindakan siswa dalam proses pembelajaran.

Ketiga, model pembelajaran

snowball throwing memiliki pengaruh terhadap kemampuan menganalisis unsurunsur teks berita siswa dan mengalami perubahan yang signifikan. Hal ini dapat dilihat dari perubahan nilai pretest dan posttest.

Berdasarkan pengajuan nilai statistik uji-t terhadap pretest dan posttest didapat hasil bahwa nilai $t_{\text {hitung }}$ yaitu 7,94 sedangkan nilai $\mathrm{t}_{\text {tabel }} 1,699$ dengan demikian, $\mathrm{t}_{\text {hitung }}>\mathrm{t}_{\text {tabel }}$ maka $\mathrm{H}_{0}$ ditolak dan $\mathrm{H}_{1}$ diterima. Dengan demikian, terdapat yang cukup signifikan antara hasil pretest dan posttest. Sehingga, dapat disimpulkan bahwa hipotesis yang telah diajukan dapat diterima, itu berarti proses pembelajaran dengan menggunakan model pembelajaran snowball throwing memberikan pengaruh terhadap siswa kelas VIII MTs Negeri 4 Sukabumi.

\section{DAFTAR PUSTAKA}

Arikunto, Suharsismi. 2012. Prosedur Penelitian Suatu Pendekatan Praktik. Jakarta : PT Rineka Group.

Aqib, Zaenal. 2013 . Model-model Pembelajaran Kontektual Inovatif. Bandung Widya

Hamdi, Asep Saepul. 2012. Metode Penelitian Kuantitatif Dalam Pendidikan. Yogyakarta: CV Budi Utama.

Isjoni. 2009. Cooperative learning Efektifitas Pembelajaran Kelompok. Bandung: Alfabeta.

Rosidi, Imran. 2009. Menulis Siapa Takut. Yogyakarta: Kanisius

Sugiono. 2016. Metode Penelitian Pendekatan Kuantitatif, Kualitatif, dan $R \& D$. Bandung: Alfabeta.

Tarigan, Henri Guntur. 2008. Menulis Sebagai Suatu Keterampilan Berbahasa. Bandung: Angkasa Bandung.

Pudiastuti, Dewi Ratna.2014. Cara dan Tip Produktif Menulis Buku. Jakarta: Alek Media Komputindo. 